\title{
PENGARUH TRANSPARANSI DAN KOMITMEN TERHADAP AKUNTABILITAS PENGELOLAAN ANGGARAN
}

\author{
Henny Hendratmi, JMV Mulyadi, dan Tri Widiastuti \\ Magister Akuntansi Universitas Pancasila \\ E-mail: amy260685@gmail.com
}

\begin{abstract}
This study aims to examine and analyze the effect of transparency and commitment to the budget management in Bekasi City simultaneously and partial in period 2014. This study uses the population, namely the budget administrator and representatives of school committees Bekasi City where in 2014 the number of high school by 70. Meanwhile, samples took as many as 210 respondents by cluster sampling method and used primary data by distributing questionnaires. From this study we concluded that transparency and commitment have simultaneously positive and significant implications againts the accountability of budget management. Furthermore the research has proved that the applied commitment positively effect to the achievement of management accountability.
\end{abstract}

Keywords: Budget Management Accountability, Transparency, Commitment

\section{PENDAHULUAN}

Anggaran pendidikan adalah alokasi anggaran untuk fungsi pendidikan yang dianggarkan melalui kementerian negara/lembaga, alokasi anggaran pendidikan melalui transfer ke daerah, dan alokasi anggaran pendidikan melalui pengeluaran pembiayaan, termasuk gaji pendidik, tetapi tidak termasuk anggaran pendidikan kedinasan, untuk membiayai penyelenggaraan pendidikan yang menjadi tanggung jawab Pemerintah. Persentase anggaran pendidikan tersebut adalah perbandingan alokasi anggaran pendidikan terhadap total alokasi anggaran belanja negara. Dalam upaya meningkatkan hasil pendidikan yang lebih optimal, pemerintah merencanakan dan mengimplementasikan kebijakan di bidang pendidikan dengan mengalokasi anggaran pendidikan sebesar $20 \%$ dari dana APBN.

Fenomena tentang akuntabilitas, saat ini semakin gencar disuarakan dengan adanya tuntutan masyarakat akan pendidikan yang bermutu. Ini membuktikan bahwa kecenderungan masyarakat pada masa kini berbeda dengan masa lalu. Di masa lalu masyarakat cenderung menerima apa pun yang diberikan oleh pendidikan, maka sekarang mereka tidak dengan mudah menerima apa yang diberikan oleh pendidikan. Masyarakat yang membayar pendidikan merasa berhak untuk memperoleh pendidikan yang lebih baik bagi dirinya dan anak-anaknya.

Konsepsi tentang akuntabilitas berkembang dari pendapat bahwa siapapun yang diserahi tugas mendidik harus dapat mempertanggungjawabkan tugasnya itu. Pengertian tanggung jawab di sini masih mengandung ukuran yang kabur. Masih banyak orang yang mengukur tanggung jawab itu dari segi masukan kealatan semata. Dalam hal ini mereka menganggap telah berhasil melaksanakan tanggung jawabnya bila telah mengajar, memberikan buku, atau secara lebih makro lagi telah membangun gedung-gedung, serta mencetak jutaan buku pelajaran.

Pelaksanaan konsep akuntabilitas dalam pendidikan di Indonesia saat ini sedang disorot mengingat banyak sekali masalah

Volume 3 No. 2 Tahun 2017, Hal. 76-93 
yang menghinggapi termasuk lembaga pendidikan yang lebih mengutamakan bisnis daripada mutu layanan pendidikan yang dijalankannya, sehingga banyak masyarakat yang mempertanyakan mengapa hal ini bisa terjadi demikian. Untuk itu, memang tidak mudah menerapkan akuntabilitas pendidikan yang baik, karena dibutuhkan kerjasama yang baik setidaknya ada enam pihak yang terlibat dalam mewujudkannya, yaitu siswa (peserta didik), guru (pendidik), administrator pendidikan, lembaga pendidikan, tenaga kependidikan, masyarakat (termasuk orang tua dan rakyat) dan pemerintah.

$$
\text { Boy dan Siringoringo (2009) }
$$

menyimpulkan bahwa semakin akurat dan tepat waktu pelaporan penggunaan dana yang dikumpulkan dari orang tua murid, maka akan semakin tinggi partisipasi orang tua murid dalam pembiayaan penyelenggaraan pendidikan, oleh karenanya dapat dihasilkan ouput pendidikan yang efektif. Darmawan (2011) dalam penelitiannya mengemukakan bahwa terdapat hubungan dan pengaruh positif serta signifikan antara transparansi dan akuntabilitas terhadap pengelolaan keuangan, pengaruh tersebut ditunjukkan secara simultan dan secara parsial. Solihat dan Sugiharto (2009) mengemukakan dalam penelitiannya bahwa trasparansi dan akuntabilitas pengelolaan pendidikan berpengaruh positif, baik secara simultan maupun parsial, terhadap tingkat partisipasi orangtua murid. Kemudian Pratama (2013) mengemukakan bahwa partisipasi masyarakat, transparansi pemerintahan dan akuntabilitas publik tidak terdapat hubungan yang positif terhadap efisiensi penyaluran dana Bantuan Operasional Sekolah (BOS) pada Sekolah Dasar (SD).

Dari beberapa temuan terhadap kasus dan permasalahan yang terjadi di atas, maka hal ini mengindikasikan bahwa pengelolaan anggaran sekolah belum berjalan secara efektif sesuai dengan sasaran dan tujuannya serta pengelolaannya belum mencerminkan prinsip akuntabilitas dan transparansi yang merupakan bagian dari prinsip dasar untuk mewujudkan good governance.

Ada pun tujuan penelitian yang ingin dicapai peneliti dalam penulisan karya ilmiah ini adalah: 1) Untuk menguji dan menganalisis pengaruh transparansi dan komitmen terhadap pengelolaan anggaran sekolah secara simultan; dan 2) Untuk menguji dan menganalisis pengaruh transparansi dan komitmen terhadap pengelolaan anggaran sekolah secara parsial.

\section{TELAAH TEORI DAN PENGEMBANGAN HIPOTESIS}

Akuntansi Perilaku (Behavioral Accounting)

Konsep perilaku (behavioral concept) pada awalnya merupakan kajian bidang utama dalam psikologi dan sosial psikologi. Akan tetapi, faktor-faktor psikologi dan sosial psikologi seperti motivasi, sikap, dan personalitas juga sangat relevan dengan bidang akuntansi (Siegel dan Marconi, 1986). Dimensi akuntansi keperilakuan terkait dengan aspek perilaku manusia dan hubungannya dengan desain, konstruksi dan penggunaan sistem informasi akuntansi yang efisien. Hal ini karena akuntansi keperilakuan merefleksikan dimensi sosial akibat penerapan teknik dan sistem akuntansi yang pada hakikatnya informasi akuntansi dibutuhkan manajemen untuk melakukan pengendalian, baik pengendalian manajemen, administratif, maupun pengendalian akuntansi. Siegel dan Marconi, 1989, mengatakan bahwa "behavioral accounting goes beyond the traditional accounting role of collecting, recording, reporting financial information". Para akuntan, peneliti operasional dan ahli manajemen telah mengembangkan faktorfaktor psikologi dan sosial psikologi termasuk pengendalian. IImu sosiologi dan psikologi juga dikonsentrasikan pada pengendalian seperti halnya sosial dan fenomena personal (Hoopwood, 1974). 


\section{TEORI PENGELOLAAN KEUANGAN NEGARA}

Sistem informasi akuntansi dalam sistem perencanaan, sistem penatausahaan (termasuk didalamnya sistem akuntabilitas), dan sistem pengendalian sektor publik mempunyai arti dan peran penting terkait pada fungsinya dalam pengukuran dan pengendalian. Dalam fungsi pengukuran, akuntansi melakukan proses pengumpulan, pencatatan realisasi pendapatan dan belanja (gaji, barang/jasa) serta transaksi-transaksi yang terjadi di luar pendapatan dan belanja, serta aktivitas pelaporan. Selanjutnya akan dapat digunakan sebagai pengukur kinerja ekonomis, efisiensi, dan efektifitas pemerintah.

Dalam pemerintahan sendiri sudah mulai ada perhatian yang lebih besar terhadap penilaian kelayakan praktek manajemen pemerintahan yang mencakup perlunya dilakukan perbaikan sistem akuntansi manajemen, sistem akuntansi keuangan, sistem perencanaan keuangan, sistem pengadaan barang atau jasa, sistem pengawasan dan pemeriksaan, serta berbagai implikasi finansial atas kebijakan-kebijakan yang dilakukan pemerintah. Organisasi sektor publik termasuk pemerintah saat ini tengah menghadapi tekanan untuk lebih efisien, memperhitungkan biaya ekonomi dan biaya sosial, serta dampak negatif atas aktivitas yang dilakukan. Berbagai tuntutan tersebut menyebabkan akuntansi dapat dengan cepat diterima dan diakui sebagai ilmu yang dibutuhkan untuk mengelola urusan-urusan publik. Akuntansi sektor publik pada awalnya merupakan aktivitas yang terspesialisasi dari suatu profesi yang relatif kecil. Namun demikian saat ini akuntansi sektor publik sedang mengalami proses untuk menjadi disiplin ilmu yang lebih dibutuhkan dan substansial keberadaannya (Mardiasmo, 2002).

Pengelolaan keuangan daerah dibagi menjadi tiga proses besar. Tiga proses tersebut adalah perencanaan (penetapan anggaran), penatausahaan (proses pelaksanaan APBS termasuk di dalamnya pengalokasian BOS) dan pelaporan (pertanggungjawaban APBS). Proses akuntansi merupakan bagian dari aktifitas pelaporan yang mengharuskan setiap pengguna anggaran untuk melaporkan seluruh transaksi ke dalam laporan keuangan.

\section{Teori Reformasi Birokrasi}

Dwiyanto (2006) mendefinisikan reformasi budaya birokrasi sebagai sebuah sistem atau seperangkat nilai yang memiliki simbol, orientasi nilai, keyakinan, pengetahuan, dan pengalaman hidup yang terinternalisasi ke dalam pikiran. Seperangkat nilai tersebut diaktualisasikan dalam sikap, tingkah laku, dan perbuatan yang dilakukan oleh setiap anggota dari sebuah organisasi yang dinamakan birokrasi. Menurut Toha (2008) bahwa membangun budaya organisasi pemerintah idealnya adalah membangun sikap dan perilaku sistem yang kemudian diikuti secara konsisten oleh pelakunya untuk menciptakan tata pemerintahan yang baik (good governance). Berdasarkan beberapa pendapat dapat disimpulkan bahwa budaya organsiasi merupakan unsur yang sangat penting bagi perkembangan reformasi dalam pengadaan barang atau jasa pemerintah. Ketika sebuah organsasi melupakan perubahan pada sisi budaya ketika melakukan perubahan organisasi, maka hal itu merupakan sebuah usaha sia-sia. Karena usaha itu akan gagal dan kondisi akan kembali ke semula.

\section{Teori Transparansi}

Transparansi merupakan salah satu prinsip good governance. Transparansi dibangun atas dasar arus informasi yang bebas, seluruh proses pemerintahan, lembaga-lembaga dan informasi perlu dapat diakses oleh pihak-pihak yang berkepentingan, dan informasi yang tersedia harus memadai agar dapat dimengerti dan dipantau. Transparansi 
pada akhirnya akan menciptakan horizontal accountability antara pemerintah daerah dengan masyarakat sehingga tercipta pemerintahan daerah yang bersih, efektif, efisien, akuntabel dan responsif terhadap aspirasi dan kepentingan masyarakat. Transparansi adalah prinsip yang menjamain akses atau kebebasan bagi setiap orang untuk memperoleh informasi tentang penyelenggaraan pemerintahan, yakni informasi tentang kebijakan proses pembuatan dan pelaksanaanya serta hasil-hasil yang dicapai.

Anggaran (budget) merupakan suatu alat perencanaan mengenai pengeluaran dan pendapatan pada masa yang akan datang, umumnya disusun secara sistematis yang meliputi seluruh kegiatan, yang dinyatakan dalam unit (kesatuan) moneter dan berlaku untuk jangka waktu (periode) tertentu di masa yang akan datang. Anggaran juga berfungsi sebagai alat kontrol atau pengawasan, baik terhadap pendapatan maupun pengeluaran pada masa yang akan datang.

Menurut Sopanah dan Mardiasmo (2003) anggaran yang disusun oleh pihak eksekutif dikatakan transparansi jika memenuhi beberapa kriteria berikut: (1) Terdapat pengumuman kebijakan anggaran, (2) Tersedia dokumen anggaran dan mudah diakses, (3) Tersedia laporan pertanggungjawaban yang tepat waktu, (4) Terakomodasinya suara/usulan rakyat, (5), Terdapat sistem pemberian informasi kepada publik.

Transparansi merupakan prasyarat untuk terjadinya partisipasi masyarakat yang semakin sehat karena (Sulistoni, 2003): (a) Tanpa informasi yang memadai tentang penganggaran, masyarakat tidak punya kesempatan untuk mengetahui, menganalisis, dan mempengaruhi kebijakan, (b) Transparansi memberi kesempatan aktor di luar eksekutif untuk mempengaruhi kebijakan dan alokasi anggaran dengan memberi perspektif berbeda dan kreatif dalam debat anggaran, (c) Melalui informasi, legislatif dan masyarakat dapat melakukan monitoring terhadap keputusan dan kinerja pemerintah. Tanpa kebebasan informasi fungsi pengawasan tidak akan efektif, (d) Berdasarkan teori yang ada menunjukkan bahwa semakin transparan sebuah kebijakan publik maka pengawasan yang dilakukan oleh dewan akan semakin meningkat karena masyarakat juga terlibat dalam mengawasi kebijakan publik tersebut.

\section{Teori Komitmen}

Komitmen adalah bentuk loyalitas yang lebih kongkrit, yang dapat dilihat dari upaya karyawan mencurahkan perhatian, gagasan dan tanggung jawab dalam mencapai tujuan perusahaan. Menurut Nasution (2007), komitmen adalah pengikat antar individu dengan suatu organisasi, gagasan atau proyek yang diwujudkan dalam mendedikasikan dirinya bagi pencapaian misi organisasi. Griffin (2005) menyatakan komitmen adalah sikap yang mencerminkan sejauh mana seseorang individu mengenal dan terikat pada organisasinya. Porter dalam Panggabean (2004) menyatakan bahwa komitmen adalah kuatnya pengenalan dan keterlibatan seseorang dalam suatu organisasi tertentu.

Mowday yang dikutip Sopiah (2008) menyatakan ada tiga aspek komitmen antara lain:

1. Affective commitment, yang berkaitan dengan adanya keinginan untuk terikat pada organisasi. Individu menetap pada organisasi karena keinginan sendiri. 
Kunci dari komitmen ini adalah (want to).

2. Continuance commitment, adalah suatu komitmen yang didasarkan kebutuhan rasional. Dengan kata lain, komitmen ini terbentuk atas dasar untung rugi, dipertimbangkan atas apa yang harus dikorbankan bila akan menetap pada suatu organisasi. Kunci dari komitmen ini adalah kebutuhan untuk bertahan (need to).

3. Normative commitment, adalah komitmen yang didasarkan pada norma yang ada dalam diri karyawan, berisi keyakinan individu akan tanggung jawab terhadap organisasi. la merasa harus bertahan karena loyalitas. Kunci dari komitmen ini adalah kewajiban untuk bertahan dalam organisasi (ought to).

\section{Teori Akuntabilitas Pengelolaan Negara}

Akuntabilitas merupakan suatu kewajiban untuk memberikan laporan kepada pihak lain tentang apa yang mereka lakukan atau tidak mereka lakukan, akuntabilitas juga menyangkut pertanggungjawaban kepada semua pihak yang berkepentingan (Jones, 2000). Sedangkan Hatry, (1980) mengemukakan akuntabilitas (accountability) merupakan suatu istilah yang diterapkan untuk mengukur apakah dana publik telah digunakan secara tepat untuk tujuan yaitu dana publik tadi ditetapkan dan digunakan secara legal.

Mengacu pada tiga pilar utama yang menjadi persyaratan akuntabilitas yaitu pertama, adanya transparansi dalam menetapkan kebijakan dan menerima masukan dan mengikut sertakan berbagai institusi. Kedua, adanya standar kinerja yang dapat diukur dalam melaksanakan tugas, fungsi dan wewenang. Ketiga, adanya partisipasi untuk saling menciptakan suasana yang kondusif dalam menciptakan pelayanan masyarakat dengan prosedur yang mudah, biaya yang murah dan pelayanan yang cepat.

Akuntabilitas keuangan merupakan pertanggungjawaban mengenai integritas keuangan, pengungkapan dan ketaatan terhadap peraturan perundang-undangan. Sasarannya adalah laporan keuangan yang mencakup penerimaan, penyimpanan dan pengeluaran keuangan instansi pemerintah. Audit terhadap pertanggungjawaban keuangan menurut Malan (1984), dalam Mardiasmo, lebih menekankan pada: 1) Audit sebagai suatu proses yang sistematis; 2) Untuk memperoleh dan mengevaluasi bukti secara objektif; 3) Asersi atas tindakan dan kegiatan ekonomi; 4) Kesesuaian dengan kriteria/standar yang telah ditetapkan; 5) Melaporkan hasilnya kepada pihak-pihak yang berkepentingan.

\section{Pengembangan Hipotesis \\ Transparansi terhadap Akuntabilitas \\ Pengelolaan Anggaran}

Transparansi pengelolaan anggaran merupakan salah satu variabel yang dapat mempengaruhi efektifitas kinerja program pendidikan, jika pengelolaan anggaran pendapatan dan belanja sekolah semakin transparan dan mencerminkan keterbukaan maka akuntabilitas yang dihasilkan akan semakin baik (Solihat dan Sugihart: 2009).

H1: Transparansi berpengaruh positif terhadap akuntabilitas pengelolaan anggaran sekolah.

\section{Komitmen terhadap Akuntabilitas Pengelolaan Anggaran}

Komitmen perangkat sekolah dalam mengelola anggaran merupakan salah satu komponen yang dapat mempengaruhi akuntabilitas pengelolaan anggaran, jika perangkat sekolah semakin komitmen dalam mengelola anggaran pendapatan dan belanja maka akuntabilitas yang dihasilkan akan akan semakin baik pula (Darmawan: 2011).

H2: Komitmen berpengaruh positif terhadap akuntabilitas pengelolaan anggaran sekolah.

Transparansi dan Komitmen terhadap Akuntabilitas Pengelolaan Anggaran 
Zeyn (2010) mengemukakan komitmen organisasi dan transparansi memiliki pengaruh positif terhadap akuntabilitas publik pada tingkat yang cukup (sedang). Kondisi ini memperlihatkan bahwa semakin baik komitmen organisasi akan mendorong keberhasilan akuntabilitas publik.

H3: Transparansi dan komitmen berpengaruh positif terhadap akuntabilitas pengelolaan anggaran sekolah.

\section{METODE ANALISIS}

\section{Operasionalisasi Variabel}

Variabel terikat dalam penelitian ini adalah akuntabilitas pengelolaan anggaran, sedangkan variable bebas adalah transparansi dan komitmen. Masing-masing definisi operasional variabel ini dijelaskan sebagai berikut:

1. Transparansi. Sopanah dan Mardiasmo (2003) menyatakan bahwa anggaran yang disusun oleh pihak eksekutif dikatakan transparansi jika memenuhi beberapa kriteria berikut: (1) Terdapat pengumuman kebijakan anggaran, (2) Tersedia dokumen anggaran dan mudah diakses, (3) Tersedia laporan pertanggungjawaban yang tepat waktu, (4) Terakomodasinya suara/usulan rakyat, (5) Terdapat sistem pemberian informasi kepada pubik. Dalam penelitian ini, indikator yang digunakan adalah berdasarkan penelitian terdahulu. Variabel ini diukur dengan skala likert 5 poin dengan 22 pernyataan yaitu 6 pernyataan mengenai anggaran, 4 pernyataan mengenai ketersediaan, 4 pernyataan mengenai pertanggungjawaban, 4 pernyataan mengenai ide dan gagasan dan 4 pernyataan mengenai informasi.

2. Komitmen. Cohen dan Uphoff (2011) menyatakan bahwa komitmen merupakan nilai sentral dalam mewujudkan soliditas organisasi untuk mendapatkan hasil: (1) Pengambilan keputusan, (2) Pelaksanaan kegiatan, (3)
Pengambilan manfaat, (4) Evaluasi. Variabel ini diukur dengan skala likert 5 poin dengan 16 pernyataan yaitu 2 pernyataan mengenai kemampuan menyesuaikan diri, 4 pernyataan mengenai produktifitas, 5 pernyataan mengenai kepuasan kerja dan 8 pernyataan mengenai kepuasan kerja.

3. Akuntabilitas Pengelolaan Anggaran. Mahmudi (2010) menyatakan bahwa pertanggungjawaban finansial yang baik harus: (1) Memiliki data yang diperoleh secara berkualitas dan dapat dipertanggungjawabkan kebenarannya serta memenuhi unsur validitas, (2) Proses pengerjaan pertanggungjawaban didukung oleh sistem informasi dan teknologi informasi yang memadai serta andal (3) Informasi yang disajikan merupakan cerminan atas keadaan yang sebenarnya, tidak direkayasa untuk tujuan tertentu (4) Analisis yang dilakukan oleh organisasi menggunakan sistem pendukung keputusan yang dapat membantu manajer dalam mengambil keputusan dan (5) Keputusan yang diambil harus berdasar pada pelaporan yang sebenarnya sebagai landasan dan dapat dipertanggunggungjawabkan secara benar. Variabel ini diukur dengan skala likert 5 poin dengan 27 pernyataan yaitu 5 pernyataan mengenai data, 5 pernyataan mengenai proses, 5 pernyataan mengenai analisis dan 7 pernyataan mengenai keputusan.

Menurut Riduwan (2011) yang menyatakan bahwa setelah diuraikan dan kemudian variabel tersebut dijabarkan menjadi dimensi-dimensi (sub variabel), kemudian manjadi indikator-indikator dan diteruskan menjadi item-item pernyataan atau pertanyaan penelitian (instrumen penelitian).

\section{Jenis dan Sumber Data}

Jenis data yang digunakan dalam penelitian ini adalah data primer. Data 
primer yaitu data-data yang dikumpulkan untuk penelitian dari tempat aktual terjadinya peristiwa (sumbernya). Data ini dapat dikumpulkan dengan beberapa cara, antara lain: kuesioner, observasi, dan hasil pengujian (Sekaran, 2006). Sumber data primer dalam penelitian ini diperoleh langsung dari responden yang dianggap representative untuk mengisi daftar pertanyaan yang dibuat melalui instrumen penelitian.

Disamping itu, data penelitian ini termasuk data kualitatif. Data kualitatif menurut Sugiono (2004) adalah data yang dinyatakan dalam bentuk kata, kalimat dan gambar. Data kualitatif ini diperoleh melalui penyebaran kuesioner yang kemudian diubah menjadi data kuantitatif, diangkakan berupa scoring untuk masing-masing pernyataan.

Skala yang digunakan dalam penelitian ini untuk pembobotan item kuesioner adalah menggunakan skala likert. Menurut Sugiyono (2012) menyatakan skala likert digunakan untuk mengukur sikap, pendapat, dan persepsi seseorang atau sekelompok orang tentang fenomena sosial. Setiap jawaban responden berturut-turut diberi nilai 5,4 , 3, 2, dan 1 dari sangat setuju jika item pertanyaan berindikasi positif dan sebaliknya setiap jawaban responden berturut-turut diberi nilai 1, 2, 3, 4, dan 5 jika item pertanyaan berindikasi negatif.

\section{Populasi dan Sampel}

Daerah yang dijadikan populasi adalah kota Bekasi yang terdiri dari Bekasi Barat, Bekasi Utara, Bekasi Selatan, Bantar Gebang, Rawa Lumbu, Medan Satria, Jati Asih, Jati Sampurna, Pondok Gede, dan Bekasi Timur. Teknik pengambilan sampel secara sampling area atau Cluster Sampling. Adapun definisi cluster sampling adalah teknik pengambilan sampel dimana pemilihan mengacu pada kelompok bukan pada individu. Sedangkan daerah penelitian yang dijadikan sampel adalah kota Bekasi Barat, Pondok Gede, dan Jati Asih, dengan sasaran utama yang diwawancarai atau mengisi kuesioner adalah Sekolah Menengah Atas Negeri dan Swasta yang berjumlah 70 Sekolah, dengan jumlah sampel sebanyak 210 orang.

\section{Metode Analisis Data Uji Validitas}

Validitas menurut Sekaran (2008-248) adalah bukti bahwa instrumen, teknik, atau proses yang digunakan untuk mengukur sebuah konsep benar-benar mengukur konsep yang dimaksud. Uji validitas bertujuan untuk mengukur valid atau tidaknya suatu item pertanyaan. Uji validitas dilakukan dengan membandingkan nilai $r$ hitung dengan $r$ table untuk degree of freedom $(\mathrm{df})=\mathrm{n}-2$.

\section{Uji Reliabilitas}

Keandalan (reliability) menurut Sekaran (2006:40) menyatakan suatu pengukuran menunjukkan sejauh mana pengukuran tersebut dilakukan tanpa bias (bebas kesalahan - error free). Oleh karena itu, menjamin pengukuran yang konsisten lintas waktu dan lintas beragam item dalam instrumen perlu dilakukan. SPSS memberi fasilitas untuk mengukur reliabilitas dengan uji statistic Cronbachs Alfa $(\alpha)$. Suatu konstruk atau variabel dikatakan reliabel jika memberikan nilai Cronbachs Alpha $>0.60$.

\section{Uji Deskriptif Data Penelitian}

Trihendradi (2011), mengemukakan pada pengukuran statististik deskriptif pada dasarnya memaparkan secara numerik dua hal pokok pengukuran data, yaitu pemusatan data (central tendency) dan penyimpangan data (dispersi). Central tendency mengukur pemusatan suatu data dengan beberapa parameter umum yaitu: 1) Mean atau ratarata, yaitu nilai rata-rata hitung; 2) Median, yaitu nilai tengah data setelah data tersebut Volume 3 No. 2 Tahun 2017, Hal. 76-93 
diurutkan dari kecil ke besar; 3) Modus, yaitu nilai yang sering muncul dari suatu data.

Sedangkan dispersi mengukur penyebaran suatu data, beberapa parameter yang digunakan untuk pengukuran dispersi suatu data, yaitu: 1) Standar deviasi, yaitu simpangan baku; 2) Variance, adalah nilai varian atau nilai kuadrat dari standar deviasi; 3) Mean adalah nilai kesalahan standar dari sampel.

\section{Uji Asumsi Klasik Uji Normalitas}

Uji normalitas bertujuan untuk mengetahui distribusi data yang digunakan dalam variabel penelitian. Data yang baik dan layak digunakan dalam penelitian adalah data yang memiliki distribusi normal (Nugroho, 2005: 18). Untuk menguji apakah data penelitian berdistribusi normal atau tidak, maka dapat dilihat melalui normal probability plot dengan membandingkan distribusi kumulatif dan distribusi normal. Data normal akan membentuk satu garis lurus diagonal, dan ploting data akan dibandingkan dengan garis diagonal. Apabila distribusi data adalah normal, maka garis yang menggambarkan data sesungguhnya akan mengikuti garis diagonalnya (Ghozali, 2006: 110).

\section{Uji Multikolinieritas}

Pada pengujian multikolinieritas bertujuan untuk mengetahui apakah ada tidaknya variabel independen yang memiliki kemiripan dengan variabel independen lainnya dalam satu model (Nugroho, 2005: 58). Uji multikolinieritas juga memiliki fungsi untuk mendeteksi terjadinya multikolineritas yang bertujuan untuk menghindari pembiasan dalam proses pengambilan keputusan. Keputusan yaitu pengaruh pada uji parsial masing-masing vaiabel independen terhadap variabel dependen. Deteksi multikolinieritas pada suatu model dapat dilihat jika nilai Variance Inflation Factor (VIF) tidak lebih dari 10 dan nilai tolerance tidak kurang dari 0,1 , maka model tersebut terbebas dari multikolinieritas. VIF = 1/Tolerance, jika VIF 10 maka Tolerance $=0,1$ (Ghozali, 2006: 92).

\section{Uji Heterosekedastisitas}

Pengujian ini dimaksudkan untuk menguji apakah model regresi terjadi kesamaan variance dari residual satu pengamatan ke pengamatan yang lain (Ghazali, 2006: 105). Model regresi yang baik adalah model regresi yang memiliki kesamaan variance residual dalam suatu periode pengamatan dengan pengamatan yang lain, atau heteroskedastisitas. Dalam menentukan ada tidaknya heteroskedastisitas pada suatu model dapat dilihat pada pola gambar scatter plot model tersebut dengan melakukan Uji Glesjer (Ghazali, 2006: 105).

\section{Uji Hipotesis (Uji F dan t)}

Dalam penelitian ini mengunakan tingkat siknifikansi ( $\dot{\alpha}) 0.05$ atau 5\%. Dalam pengambilan keputusan untuk diterima atau ditolak maka dilakukan pengujian terhadap variabel-variabel penelitian dengan cara menguji secara simultan melalui signifikansi simultan (uji statistik F). Maksud dari pengujian ini untuk dapat menjelaskan apakah semua variabel independen atau bebas yang dimasukkan dalam model mempunyai pengaruh secara bersama-sama terhadap variabel dependen atau terikat (Ghozali, 2006: 84). Untuk itu hipotesis statistiknya adalah sebagai berikut:

Ho: $ß 1=ß 2=\ldots=ß k=0$

Ha: $ß 1 \neq ß 2 \neq \ldots \neq \beta k \neq 0$

Artinya apakah semua variabel independen secara simultan merupakan variabel penjelas yang signifikan terhadap variabel dependen. Dengan menentukan taraf signifikansi $(\alpha=5 \%)$. Nilai $F$ tabel diperoleh dengan menggunakan tingkat signifikansi á dan derajat kebebasan (df) tertentu. Dengan membandingkan antara nilai $F$ hitung dan $F$ tabel, jika dalam 
perhitungan $\mathrm{F}$ hitung $>\mathrm{F}$ tabel, maka $\mathrm{HO}$ ditolak dan $\mathrm{Ha}$ diterima. Sedang pada pengujian masing-masing variabel secara parsial, dilakukan uji signifikansi parameter individual (uji t statistik) yang memiliki tujuan untuk mengetahui seberapa jauh pengaruh satu variabel independen secara individual dalam mempengaruhi variasi variabel dependen, dalam hipotesis statistik dapat dilil

$$
Y=\dot{\alpha}+ß 1 \times 1+ß 2 \times 2+e
$$

$\mathrm{HO}: ß i=0$

Ha: $ß i \neq 0$

Artinya, apakah suatu variabel independen merupakan atau bukan merupakan penjelas yang signifikan terhadap variabel dependen. Dengan mengunakan taraf signifikansi ( $\alpha=5 \%)$. Dengan membandingkan antara nilai $t$ hitung maka dapat ditentukan kriteria pengujian sebagai berikut:

Apabila t hitung $<\mathrm{t}$ tabel, maka $\mathrm{HO}$ diterima Ha ditolak.

Apabila t hitung > t tabel, maka $\mathrm{HO}$ ditolak $\mathrm{Ha}$ diterima.

\section{Uji Regresi Berganda}

Analisis regresi digunakan untuk mengetahui seberapa besar perubahan nilai $Y$ (variabel terikat) apabila nilai X (variabel bebas) berubah satu satuan unit tertentu, menguji pengaruh lebih dari satu variabel bebas terhadap satu variabel terikat (Ghozali. 2006:7). Model persamaan regresi linear berganda yang digunakan adalah sebagai berikut:

$$
\begin{aligned}
& \text { Keterangan: } \\
& \mathrm{Y}=\text { Akuntabilitas } \\
& \alpha=\text { Konstanta } \\
& \mathrm{X} 1=\text { Transparansi } \\
& \mathrm{X} 2=\text { Komitmen } \\
& \text { e }=\text { Error }
\end{aligned}
$$

\section{Uji Koefisien Determinasi}

Koefisien determinasi $\left(R^{2}\right)$ pada intinya untuk mengukur seberapa jauh kemampuan model dalam menerangkan variasi dependen. Nilai koefisien determinasi berkisar antara nol dan satu, nilai $\mathrm{R}^{2}$ yang kecil berarti kemampuan variabel-variabel independen dalam menjelaskan variasi variabel dependen sangat terbatas. Nilai yang mendekati satu berarti variabel independen memberikan hampir semua informasi yang dibutuhkan untuk memprediksi variasi variabel dependen (Ghozali, 2006).

\section{HASIL DAN PEMBAHASAN Hasil Uji Statistik Deskriptif}

Tabel 1. Hasil Uji Deskripsi Data Penelitian

Descriptive Statistics

\begin{tabular}{|l|r|r|r|r|r|r|}
\hline & N & Minimum & Maximum & \multicolumn{1}{|c|}{ Mean } & Std. Deviation & Variance \\
\hline x1 & 127 & 75.00 & 145.00 & 120.1181 & 10.42784 & 108.740 \\
X2 & 127 & 75.00 & 118.00 & 96.5827 & 8.59535 & 73.880 \\
Y & 127 & 78.00 & 135.00 & 113.4409 & 10.42407 & 108.661 \\
Valid N (listwise) & 127 & & & & & \\
\hline
\end{tabular}

Sumber: Data diolah.

Berdasarkan pada pengolahan data tersebut di atas diperoleh analisis deskriptif yang memiliki karakteristik sebagai berikut: (N) menunjukkan jumlah data sebesar 127 , maka karakeristik masing-masing variabel dapat diuraikan sebagai berikut:

a. Transparansi pengelolaan anggaran (X1), dari keseluruhan sampel ( $\mathrm{n}$ ) sebanyak 127 didapat komposisi nilai sebagai berikut: 
nilai terkecil (minimum) adalah 75,00 dan terbesar (maksimum) adalah 145,00. Nilai rata-rata (mean) adalah sebesar 120,1181 dan standar deviasi 10,42784 serta nilai varians adalah 108,470.

b. Komitmen pengelolaan anggaran (X2), dari keseluruhan sampel (n) sebanyak 127 didapat komposisi nilai sebagai berikut: nilai terkecil (minimum) adalah 75,00 dan terbesar (maksimum) adalah 118,00. Nilai rata-rata (mean) adalah sebesar 96,5827 dan standar deviasi 8,59535 serta nilai varians adalah 73,880 .

c. Akuntabilitas pengelolaan anggaran $(\mathrm{Y})$, dari keseluruhan sampel (n) sebanyak 127 didapat komposisi nilai sebagai berikut: nilai terkecil (minimum) adalah 75,00 dan terbesar (maksimum) adalah 118,00 Nilai rata-rata (mean) adalah sebesar 96,5827 dan standar deviasi 8,59535 serta nilai varians adalah 73,880 .

\section{Hasil Pengujian Reliabilitas}

Tabel 2. Hasil Pengujian Reliabilitas Per-Variabel Item-Total Statistics

\begin{tabular}{|l|r|r|r|r|}
\hline & $\begin{array}{c}\text { Scale Mean if Item } \\
\text { Deleted }\end{array}$ & $\begin{array}{c}\text { Scale Variance if } \\
\text { Item Deleted }\end{array}$ & $\begin{array}{c}\text { Corrected Item- } \\
\text { Total Correlation }\end{array}$ & $\begin{array}{c}\text { Cronbach's } \\
\text { Alpha if Item } \\
\text { Deleted }\end{array}$ \\
\hline X1 & 210.0236 & 270.087 & .764 & $\mathbf{6 4 8}$ \\
X2 & 233.5591 & 376.026 & .572 & .844 \\
Y & 216.7008 & 285.799 & .698 & $\mathbf{. 7 2 2}$ \\
\hline
\end{tabular}

Sumber: Data diolah.

Berikut ini merupakan hasil uji reliabilitas dari masing-masing variabel:

1. $\mathrm{X} 1$ (Transparansi) $=0,648$

2. $X 2$ (Komitmen) $=0,844$

3. $Y$ (Akuntabilitas) $=0,722$

Berdasarkan pada hasil perhitungan Cronbachs Alpha Based on Standardized Items (yang dicetak tebal) dari total variabel dan pengujian masing-masing variabel di atas tidak ada satupun variabel yang nilainya kurang dari 0,60, hal ini menunjukkan bahwa konstruk tersebut reliabel artinya masing-masing variabel dapat disebut reliabel dan layak.

\section{Hasil Pengujian Validitas}

Tabel 3. Hasil Pengujian Validitas Total antar Variabel

\begin{tabular}{|l|r|r|r|r|}
\hline & $\begin{array}{c}|c| \\
\text { Item-Total Statistics } \\
\text { Scale Mean if Item } \\
\text { Deleted }\end{array}$ & $\begin{array}{c}\text { Scale Variance if } \\
\text { Item Deleted }\end{array}$ & $\begin{array}{c}\text { Corrected Item- } \\
\text { Total } \\
\text { Correlation }\end{array}$ & $\begin{array}{c}\text { Cronbach's Alpha } \\
\text { if Item Deleted }\end{array}$ \\
\hline x1 & 210.0236 & 270.087 & $\mathbf{7 6 4}$ & .648 \\
x2 & 233.5591 & 376.026 & $\mathbf{. 5 7 2}$ & .844 \\
y & 216.7008 & 285.799 & $\mathbf{. 6 9 8}$ & .722 \\
\hline
\end{tabular}

Sumber: Data diolah.

Berdasarkan tabel 3 di atas, tidak ada Corrected Item-Total Correlation (cetak tebal) yang kurang dari 0,1729, hal tersebut menunjukan 127 butir pertanyaan kuesioner untuk semua variabel $X 1, \quad X 2$ dan $Y$ menunjukkan angket yang valid, sehingga kuesioner dalam penelitian ini layak untuk digunakan. 


\section{Hasil Pengujian Asumsi Klasik}

\section{Hasil Pengujian Normalitas}

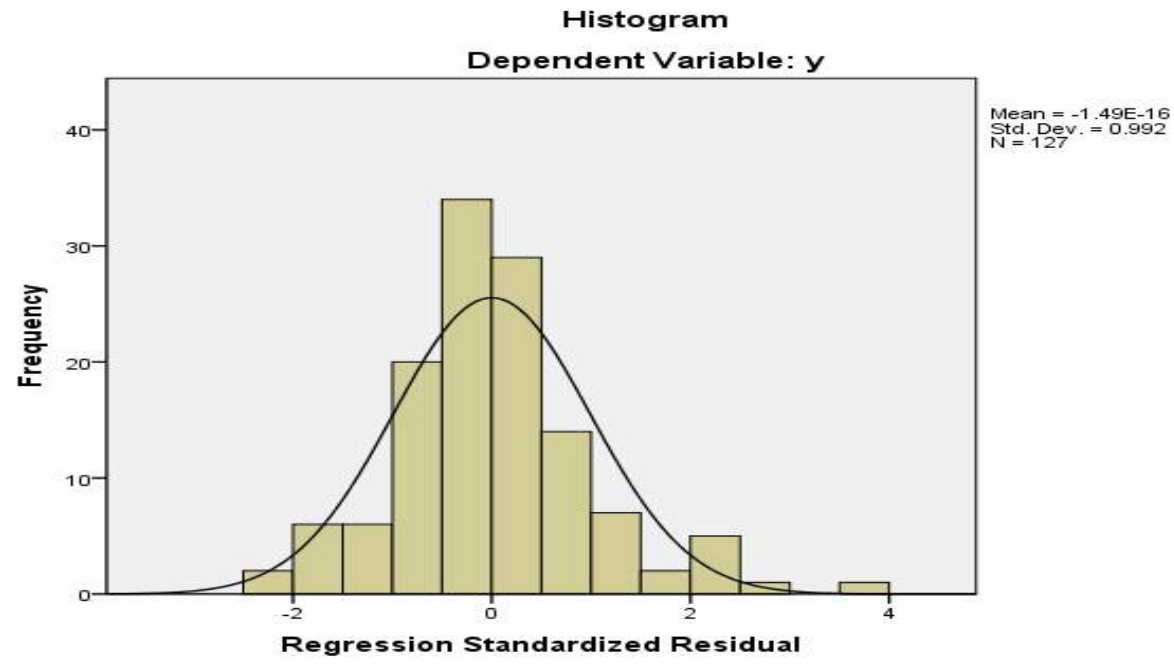

Sumber: data olahan

Gambar 1. Grafik Histogram Hasil Uji Normalitas

Dari grafik Histogram di atas dapat disimpulkan bahwa residual terdistribusi secara normal dengan ditandai penyebaran

membentuk lonceng yang tidak menjauh dari garis regresi.

\section{Hasil Uji Heteroskedastisitas}

Scatterplot

Dependent Variable: y

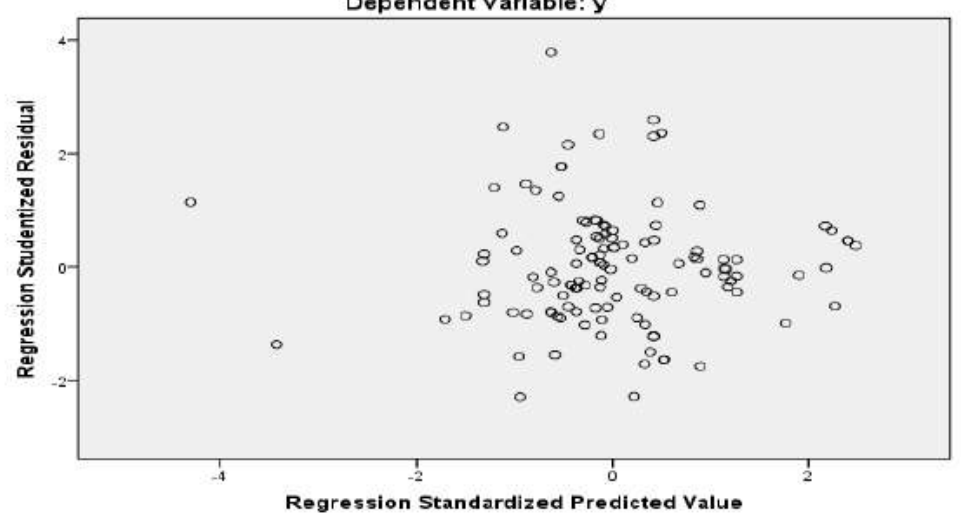

Sumber: Data diolah.

Gambar 2. Grafik Scatter Plots

Dari grafik scatter plots terlihat bahwa titik-titik menyebar secara acak serta tersebar baik di atas maupun di bawah angka 0 pada sumbu $Y$ serta tidak membentuk pola tertentu. Oleh karena itu dapat disimpulkan bahwa tidak terjadi heteroskedastisitas pada model regresi, sehingga model regresi dinyatakan layak untuk digunakan.

\section{Hasil Pengujian Multikolinieritas}

JIAFE (Jurnal Ilmiah Akuntansi Fakultas Ekonomi) Volume 3 No. 2 Tahun 2017, Hal. 76-93 
Tabel 4. Hasil Uji Multikolinieritas

Coefficients $^{\mathrm{a}}$

\begin{tabular}{|c|c|c|}
\hline \multirow[b]{2}{*}{ Model } & \multicolumn{2}{|c|}{ Collinearity Statistics } \\
\hline & Tolerance & VIF \\
\hline $1 \quad$ (Constant) & & \\
\hline$x 1$ & .669 & 1.495 \\
\hline$x 2$ & .669 & 1.495 \\
\hline
\end{tabular}

Sumber data diolah

Hasil perhitungan nilai tolerance menunjukan tidak ada variabel independen yang memiliki tolerance kurang dari 0,10 yang berarti tidak ada korelasi antar variabel independen yang nilainya lebih dari 95\%. Hasil perhitungan nilai Variance Inflation Factor (VIF) juga menunjukan hal yang sama, tidak ada satu variabel independen yang memiliki nilai VIF lebih dari 10. Jadi dapat disimpulkan bahwa tidak terdapat multikolineritas antar variabel independen dalam model regresi. Hal ini dapat dilihat dari perincian sebagai berikut:
1) VIF $X 1$ sebesar $1,495<10$ dengan nilai tolerance 0,669 > 0,10 maka menunjukkan data pengaruh transparansi tidak mengalami multikolinier.

2) VIF $X 2$ sebesar $1,495<10$ dengan nilai tolerance 0,669 > 0,10 maka menunjukkan data pengaruh komitmen tidak mengalami multikolinier.

\section{Hasil Uji Regresi}

Tabel 5. Hasil Uji Regresi Berganda Coefficients $^{\mathrm{a}}$

\begin{tabular}{|ll|r|r|}
\hline \multirow{2}{*}{\multicolumn{2}{|c|}{ Model }} & \multicolumn{2}{|c|}{ Unstandardized Coefficients } \\
\cline { 2 - 4 } & \multicolumn{2}{|c|}{ B } & \multicolumn{1}{|c|}{ Std. Error } \\
\hline 1 & (Constant) & $\mathbf{2 0 . 9 0 5}$ & 8.171 \\
& x1 & $\mathbf{6 7 0}$ & .075 \\
& x2 & .124 & .090 \\
\hline
\end{tabular}

a. Dependent Variable: $y$

Sumber: data diolah

Berdasarkan tabel 5 di atas, maka dapat diperoleh persamaan regresi sebagai berikut:

$$
Y=20.905+0.670 \times 1+0.124 X 2+e
$$

\section{Keterangan:}

$\mathrm{X} 1=$ Pengaruh Transpransi

$\mathrm{X} 2=$ Pengaruh Komitmen

$\mathrm{Y}=$ Akuntabilitas

$\mathrm{e} \quad=$ Error
Dari hasil penelitian diperoleh persamaan regresi dan dapat diintepretasikan sebagai berikut:

a. Konstanta sebesar 20,905 artinya apabila tidak ada pengaruh transparansi dan komitmen, maka nilai akuntabilitas sebesar 20,905.

b. Koefisien regresi pengaruh transparansi sebesar 0,670 artinya apabila pengaruh transparansi meningkat 1 satuan dan 
variabel lain tetap, maka akan berpengaruh terhadap kenaikan akuntabilitas sebesar 0,670 satuan.

c. Koefisien regresi pengaruh komitmen sebesar 0,124 artinya apabila pengaruh komitmen meningkat 1 satuan dan variabel lain tetap, maka akan berpengaruh terhadap akuntabilitas sebesar 0,124 satuan.

\section{Hasil Pengujian Hipotesis Hasil Uji Simultan (Uji F)}

Uji F statistik dilakukan untuk melihat secara bersama-sama (simultan) apakah ada pengaruh signifikan variabel bebas (pengaruh transparansi dan komitmen) terhadap variabel terikat (akuntabilitas pengelolaan anggaran). Rumusan hipotesis yang digunakan dalam uji F statistik adalah sebagai berikut:

Rumusan hipotesis yang digunakan dalam uji F statistik adalah sebagai berikut. Ha1: Transparansi dan komitmen berpengaruh simultan terhadap akuntabilitas pengelolaan anggaran. Dari hasil olah data mengunakan analisis regresi dalam SPSS, diperoleh output hasil Uji F pada tabel 6 sebagai berikut:

Tabel 6. Hasil Pengujian Hipotesis Statistik F

ANOVA $^{\mathrm{b}}$

\begin{tabular}{|ll|r|r|r|c|}
\hline \multicolumn{1}{|l|}{ Model } & \multicolumn{1}{|c|}{ Df } & Mean Square & F & Sig. \\
\hline 1 & Regression & 2 & 3692.628 & $\mathbf{7 2 . 6 1 1}$ & $.000^{\mathrm{a}}$ \\
& Residual & 124 & 50.855 & & \\
& Total & 126 & & & \\
\hline
\end{tabular}

a. Predictors: (Constant), $x 2, x 1$

b. Dependent Variable: $y$

Sumber data diolah

Dari tabel 6 dapat dianalisis bahwa nilai $F$ hitung sebesar 72,611 lebih besar dari $F$ Tabel sebesar 3,07 dengan $n=127$ dan $k=2$, serta nilai signifikansi sebesar 0,00 atau lebih kecil dari 0,05 ( $\alpha=5 \%)$ sehingga hipotesis alternatif satu (Ha1) diterima dan menolak hipotesis nol ( $\mathrm{HO})$, artinya bahwa transparansi dan komitmen berpengaruh secara simultan terhadap akuntabilitas pengelolaan anggaran.

\section{Hasil Uji Parsial (Uji t)}

Uji statistik $\mathrm{t}$ dilakukan untuk setiap variabel bebas (pengaruh transparansi dan komitmen) apakah mempunyai pengaruh yang signifikan terhadap variabel terikat (akuntabilitas penegelolaan anggaran) secara parsial. Berdasarkan hasil perhitungan uji statistik t dengan SPSS ver 19 pada tabel 4.8 maka diperoleh data, dan dapat disimpulkan:

Tabel 7. Hasil Uji Statistik t

Coefficients $^{\mathrm{a}}$

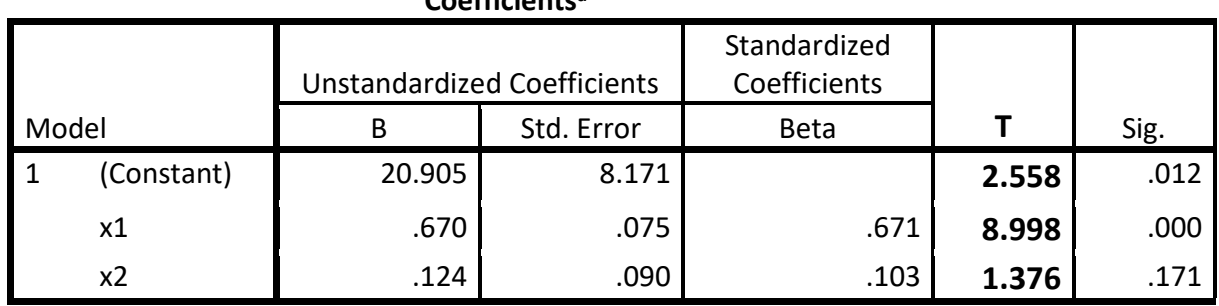

a. Dependent Variable: $y$ 
1) Variabel transparansi memiliki t hitung sebesar 8,998 lebih besar dari $t$ tabel sebesar 1,978 dengan nilai signifikansi 0,000 atau lebih kecil dari 0,05 (alpha $\alpha=$ $5 \%)$, sehingga hipotesis alternatif satu (Ha1) diterima dan menolak hipotesis nol (Ho) artinya bahwa: transparansi mempunyai pengaruh positif. Berdasarkan variabel hitung di parameter statistik $T$ hitung lebih besar dari $\mathrm{T}$ table. Artinya transaparansi berpengaruh terhadap akuntabilitas pengelolaan anggaran.
Kesimpulannya menerima Ha1 dan menolak Ho.

2) Variabel komitmen memiliki t hitung sebesar 1,376 lebih kecil dari $t$ tabel sebesar 1,978 dengan nilai signifikansi 0,171 atau lebih besar 0,05 (alpha $\alpha=5 \%$ ), sehingga hipotesis alternatif kedua ( $\mathrm{Ha} 2)$ ditolak dan menerima hipotesis nol ( $\mathrm{Ho})$ artinya bahwa: komitmen tidak mempunyai pengaruh positif terhadap akuntabilitas pengelolaan anggaran. Berdasarkan variabel hitung di parameter statistik $\mathrm{T}$ hitung lebih kecil dari $\mathrm{T}$ tabel.

\section{Hasil Uji Determinasi}

Tabel 8. Hasil Uji Determinasi

Model Summary

\begin{tabular}{l|r|r|r|c|}
\hline Model & $\mathrm{R}$ & R Square & $\begin{array}{c}\text { Adjusted R } \\
\text { Square }\end{array}$ & $\begin{array}{c}\text { Std. Error of the } \\
\text { Estimate }\end{array}$ \\
\hline 1 & $.734^{\mathrm{a}}$ & .539 & $\mathbf{. 5 3 2}$ & 7.13129 \\
\hline
\end{tabular}
a. Predictors: (Constant), x2, x1
b. Dependent Variable: $\mathrm{y}$
Sumber data diolah

Dari Tabel 8 di atas dapat dikatakan bahwa pengaruh transparansi dan komitmen adalah besar terhadap variabel terikat yaitu akuntabilitas pengelolaan anggaran. Hal ini berarti model yang digunakan semakin kuat untuk menerangkan pengaruh variabel bebas yang diteliti terhadap variabel terikat. Pada tabel 8 menunjukkan bahwa koefisien determinasi yang dilihat dari nilai adjusted $R$ square sebesar 0,532. Hal ini berarti bahwa $53.2 \%$ Y dapat dijelaskan pengaruh langsung oleh variasi kedua variabel independen yaitu $\mathrm{X} 1$ dan $\mathrm{X} 2$, sedangkan sisanya sebesar $(100 \%$ $-53.2 \%=46,8 \%$ ) dijelaskan oleh sebab lain di luar model atau variabel lain yang tidak diteliti.

\section{Pembahasan Hasil Penelitian \\ Pengaruh Transparansi terhadap \\ Akuntabilitas Pengelolaan Anggaran \\ Berdasarkan pada hasil pengolahan} data secara kuantitatif dalam penelitian ini, maka didapatkan hasil yang menyatakan bahwa terdapat pengaruh secara positif dan signifikan antara transparansi terhadap akuntabilitas pengelolaan anggaran. Dengan adanya hasil tersebut maka pertanyaan dalam rumusan permasalahan yang dikemukakan dalam penelitian pada bagian sebelumnya sudah dapat dibuktikan dan hal ini telah sesuai dan konsisten dengan hipotesis alternatif ( $\mathrm{Ha} 2$ ) yang dikemukakan pada bab sebelumnya, yaitu transparansi diduga berpengaruh positif terhadap akuntabilitas pengelolaan anggaran. Sebagaimana telah diuraikan pada bagian sebelumnya bahwa transparansi adalah dengan bahasa lain diartikan keterbukaan (openness) pemerintah dalam memberikan informasi yang terkait dengan aktivitas pengelolaan sumberdaya publik kepada pihak-pihak yang membutuhkan informasi Mardiasmo (2009). Sehingga dengan 
demikian hipotesis null $(\mathrm{HO})$ penelitian ditolak, tidak diterima dan tidak berlaku.

Sehingga dengan demikian hasil penelitian dan didukung dengan berbagai teori dapat disimpulkan bahwa jika semakin tinggi, baik dan besar transparansi yang dipraktekkan atau diimplementasikan oleh aparat pemerintah meningkat maka berkontribusi pada semakin besar pula penilaian akuntabilitas pengelolaan anggaran kepada aparat pemerintah maupun pihak swasta, transparansi di bidang keuangan khususnya masih menjadi aspek yang sangat berat dan sulit dilakukan oleh aparat pemerintah hingga saat ini. Hal tersebut dibuktikan dengan masih banyaknya fraud atau kecurangan yang berkaitan dengan pengelolaan keuangan publik, di Indonesia masih banyak sekali penyelewengan dalam penggunaan dan pengelolaan keuangan negara dari yang semestinya dan diperuntukan serta kegunaannya. Pada hakekatnya transparansi dapat dibangun atas dasar kebebasan arus informasi proses proses, lembaga - lembaga dan informasi secara langsung dapat diterima oleh mereka yang membutuhkan informasi harus dapat dipahami dan dapat dimonitor oleh semua pihak.

Hasil penelitian ini telah sejalan dan konsisten sebagaimana hasil dari penelitian sebelumnya yang dilakukan oleh Darmawan (2003), yang membahas mengenai akuntabilitas dan transparansi terhadap pengelolaan keuangan Madrasah yang berkesimpulan, bahwa terdapat hubungan dan pengaruh positif serta signifikan antara transparansi dan akuntabilitas terhadap pengelolaan keuangan, pengaruh tersebut ditunjukkan secara simultan dan secara parsial.

Oleh karenanya dari hasil penelitian ini dapat disimpulkan berdasarkan hasil uji koefisien determinasi didapat nilai sebesar $53,2 \%$, sehingga dengan demikian diperoleh interpretasi bahwa transparansi dan komitmen bukan satu-satunya sebagai faktor utama penentu dalam keberhasilan tercapainya akuntabilitas pengelolaan keuangan, namun ada faktor lain yang berpengaruh juga terhadap baik buruknya pengelolaan dana pemerintah kepada publik.

\section{Pengaruh Komitmen terhadap Akuntabilitas Pengelolaan Anggaran}

Berdasarkan pada hasil pengolahan data penelitian ini, didapatkan hasil yang menyatakan bahwa tidak terdapat pengaruh komitmen terhadap akuntabilitas pengelolaan anggaran. Sebagaimana telah diuraikan pada bagian sebelumnya bahwa komitmen merupakan kemampuan dan kemauan untuk menyelaraskan perilaku pribadi dengan kebutuhan, prioritas dan tujuan organisasi, hal tersebut menyangkut cara-cara dalam mengembangkan tujuan atau memenuhi kebutuhan organisasi yang intinya mendahulukan misi organisasi daripada kepentingan pribadi seperti yang dikemukakan oleh Soekijan (2009).

Sehingga dengan hasil penelitian khususnya komitmen masih menjadi aspek yang sangat berat dan sulit dilakukan oleh aparat pemerintah. Adanya kesulitan aparat pemerintah dalam berkomitmen terhadap tujuan yang ingin dicapai, serta dalam setiap program pemerintah jangka pendek maupun panjang. Berbeda dengan hasil penelitian terdahulu bahwa komitmen organisasi yang tinggi berpengaruh signifikan terhadap pencapaian kinerja yang baik (Keller (1997) dalam Darma, 2004). Kemudian lebih lanjut dikemukakan, komitmen organisasi dapat merupakan alat bantu psikologis dalam menjalankan organisasinya untuk pencapaian sasaran yang diharapkan, pendapat ini dikemukakan pula oleh Nouri dan Parker (1996); McClurg (1999); Chong dan Chong (2002); Wentzel (2002); dan Darma (2004). Penelitian ini konsisten dengan yang dikemukakan oleh hasil penelitian oleh Herlin (2010) menunjukkan tidak terdapat pengaruh antara komitmen organisasi terhadap kinerja organisasi melalui akuntabilitas publik. 
Sedangkan dari penelitian lainnya menunjukkan terdapat pengaruh signifikan antara variabel komitmen organisasi dalam memoderasi partisipasi penyusunan anggaran dengan kinerja aparat pemerintah daerah (Bambang, 2006). Zeyn berpendapat bahwa komitmen organisasi memiliki pengaruh positif terhadap akuntabilitas publik pada tingkat yang cukup (sedang). Kondisi ini memperlihatkan bahwa semakin baik komitmen organisasi akan mendorong keberhasilan akuntabilitas publik.

Oleh karenanya berdasar dari hasil penelitian yang dapat disimpulkan melalui hasil uji koefisien determinasi yang merupakan pengaruh langsung variabel penelitian bebas terhadap akuntabilitas didapat nilai sebesar 53,2\% dengan demikian komitmen dan transparansi bukan satusatunya sebagai faktor utama penentu dalam keberhasilan tercapainya akuntabilitas pengelolaan keuangan, namun ada faktor lain yang berpengaruh juga terhadap baik buruknya pengelolaan dana aparat pemerintah maupun swasta kepada publik yang tidak diteliti.

\section{PENUTUP}

Mengacu pada hasil penelitian yang telah diuraikan pada bagian sebelumnya, dapat diambil kesimpulan:

1. Telah terbukti secara simultan bahwa transparansi dan komitmen, berimplikasi secara positif dan signifikan terhadap pengelolaan anggaran. Dari hasil interpretasi data didapatkan suatu kesimpulan yang menyatakan semakin besar, tinggi transparansi dan komitmen aparat yang ditunjukan dalam bentuk pengelolaan keuangan yang tertuang dalam anggaran, maka akan semakin baik pula pengaruhnya terhadap pencapaian akuntabilitas pengelolaan dana tersebut.

2. Berdasarkan dari hasil penelitian telah terbukti juga bahwa tranparansi berimplikasi secara positif dan signifikan terhadap akuntabilitas pengelolaan anggaran. Hal ini berarti semakin transparan aparat pemerintah maupun swasta dalam melakukan pengelolaan dana yang berasal dari publik dan untuk publik, maka hasil yang didapat akan berpengaruh positif terhadap pencapaian akuntabilitasnya, hal ini didukung dengan hasil uji t untuk variabel transparansi (X1). Dengan transparansi yang dilakukan oleh aparat pemerintah yang ada pada lembaga pendidikan formal, pada saat ini belum dapat berjalan dengan maksmimal, khususnya dalam masalah keuangan karena masih terdapat penggunaan dana yang tidak tepat pada sasaran dan tidak diketahui peruntukannya, sasaran serta tujuannya. Oleh karenanya hasil yang didapat dalam pelaksanaan program pembelajaran belum dapat dikatakan berhasil dan berjalan dengan efektif, karena kinerja yang dihasilkan dalam angka partisipasi kasar yang merupakan salah satu indikator keberhasilan pendidikan masih belum mencapai tuntas paripurna, bahkan masih jauh dibawahnya pada kota Bekasi.

3. Hasil penelitian telah membuktikan bahwa komitmen (X2) yang diterapkan berimplikasi secara positif terhadap tercapainya akuntabilitas. Hal ini berarti bahwa semakin tinggi komitmen yang dilakukan aparatur pemerintah, maka semakin baik dan besar pula pengaruhnya terhadap akuntabilitas dalam pengelolaan dana anggaran publik. Dengan komitmen yang baik dilakukan oleh aparatur pemerintah dalam mengelola anggaran, diharapkan penggunaan dana dapat sesuai dengan perencanaan dan peruntukannya sehingga dalam mencapai tujuan yaitu tuntasnya paripurna dalam program dapat terwujud dengan baik. Namun demikian kajian di dalam penelitian ini didapat belum tingginya komitmen dari masingmasing aparatur pemerintah membuat kinerja yang dihasilkan belumlah maksimal, dan sangat berpengaruh 
terhadap keadaan yang membuat belum berhasilnya upaya pemerintah dalam menaikan Angka Partisipasi Kasar (APK) secara menyeluruh. Perencanaan pemerintah yang diimplematasikan oleh aparaturnya belum berhasil dengan optimal, selama periode penelitian menunjukkan tidak tercapainya akuntabilitas yang berakibat terhadap pengaruh kinerja pemerintahan Kota Bekasi.

\section{DAFTAR PUSTAKA}

Arimbi. 1993. Peran Serta Masyarakat Dalam Mengelola Lingkungan. Jakarta: Walhi.

Bappenas dan Depdagri. 2002. Pedoman Penguatan Pengamanan Program Pembangunan Daerah. Jakarta: Bappenas dan Depdagri.

Bastian, Indra. 2006. Sistem Perencanaan dan Penganggaran Pemerintah Daerah di Indonesia. Jakarta: Salemba Empat.

Boy, Denny dan Hotniar Siringoringo. 2009. Analisis Pengaruh Akuntabilitas dan Transparansi Pengelolaan Anggaran Pendapatan dan Belanja Sekolah (APBS) terhadap Partisipasi Orang Tua Murid. Jurnal Elektronik, Vol. 14 No. 2. Depok: Universitas Gunadarma.

Bahtiar, Arief, Muchlis dan Iskandar. 2009. Akuntansi Pemerintahan, Cetakan Pertama. Jakarta: Akademia.

Dajan, Anto. 1991. Pengantar Metode Statistik Jilid I. Jakarta: LP3ES.

Dwiyanto, Agus. 2006. Mewujudkan Good Geovernance Melalui Pelayanan Public. Yogyakarta: UGM Press.

Ghazali, Imam. 2006. Aplikasi Analisis Multivariate Dengan Program SPSS, Cetakan IV. Semarang: Badan Penerbit Universitas Diponegoro Semarang.

Griffin, Jill. 2005. Customer Loyalty: Menumbuhkan dan Mempertahankan Kesetiaan Pelanggan. Jakarta: Erlangga.
Gunawan, Adi Saputro dan Marwan Asri. 1989. Anggaran Perusahaan, Edisi Ketiga. Yogyakata: Penerbit BPFE.

Hopwood, Anthony. 1974. Acounting and Human Behaviour, First Edition. Englewood Cliffs, N.J. : Prentice-Hall.

Lembaga Administrasi Negara Republik Indonesia. 2000. Pedoman Penyusunan Pelaporan Akuntabilitas Kinerja Institusi Pemerintah. Jakarta: Lembaga Administrasi Negara dan Badan Pengawas Keuangan Negara

Mahmudi. 2010. Manajemen Kinerja Sektor Publik, Edisi ke 2. Yogyakarta: Penerbit UPP STIM YKPN.

Mardiasmo. 2002. Akuntansi Sektor Publik. Yogyakarta: Penerbit Andi. . 2004. Otonomi \& Manajemen Keuangan Daerah. Yogyakarta: Penerbit ANDI. 2003. Konsep Ideal Akuntabilitas dan Transparansi Organisasi Layanan Publik, Majalah Swara MEP, Vol. 3 No. 8 Maret. Yogjakarta: MEP UGM. 2005. Akuntansi Sektor Publik. Yogyakarta: Penerbit ANDI.

Mubyarto. 1998. Pembangunan dan Pemberdayaan Masyarakat. Yogyakarta: Pustaka Pelajar.

Nasir, Mohammad. 1999. Metode Penelitian. Jakarta: Penerbit Ghalia Indonesia.

Nasution. 2007. Perilaku Manusia. Medan: Program Studi Psikologi Fakultas Kedokteran Universitas Sumatra Utara.

Noordiawan, Deddy, dkk. 2006. Akuntansi Pemerintahan, Cetakan Kedua. Jakarta: Salemba Empat.

Panggabean, S., Mutiara. 2004. Manajemen Sumber Daya Manusia. Bogor: Ghalia Indonesia.

Pratama, 2013. Pengaruh Partisipasi Masyarakat, Transparansi Pemerintah dan Akuntabilitas Publik Terhadap Efesiensi Penyaluran Dana BOS Pada Sekolah Dasar Di Kecamatan Tanjungpinang Timur, Skripsi. 
Tanjungpinang: Fakultas Ekonomi Universitas Maritim Raja Ali.

Siegel, Gary. 1986. Behaviour Acounting. Nashville: South-Western Publishing Company.

Sugiyono. 2007. Metode Peneliian Bisnis, Cetakan Kesepuluh. Bandung: CV Alfabeta.

Sulistoni, G.. 2003. Fiqh korupsi: Amanah Vs Kekuasaan. Nusa Tenggara Barat: SOMASI.

Sekaran, Uma. 2006. Metodologi Penelitian Untuk Bisnis (Research Methods for Business ), Edisi 4. Jakarta: Salemba Empat.

Solihat, Eli dan Toto Sugiharto. 2009. Pengaruh Transparansi dan Akuntabilitas Pengelolaan Pendidikan terhadap partisipasi Orang Tua Murid di SMA Negeri 107 Jakarta. Jurnal Elektronik, Vol. 14 No. 2. Depok: Universitas Gunadarma.
Sopiah. 2008. Perilaku Organisasi. Yogyakarta: Penerbit Andi.

Thoha, Miftah. 2008. Perilaku Organisasi: Konsep Dasar dan Aplikasinya. Jakarta: Raja Grafindo Persada.

Trihendradi. 2011. Analisis Statistik mengunakan SPSS 19 Deskriptif Parametrik dan Non Parametrik. Yogyakarta: Penerbit Andi.

Widodo, Joko. 2001. Good Governance, Telaah dari Dimensi Akuntabilitas dan Kontrol Birokrasi Pada Era Desentralisasi dan Otonomi Daerah. Surabaya: Penerbit Insan Cendikia.

Peraturan Pemerintah No 24 Tahun 2005. Tentang Standar Akuntansi Pemerintahan.

Peraturan Pemerintah No 71 Tahun 2010. Tentang Standar Akuntansi Pemerintahan. 